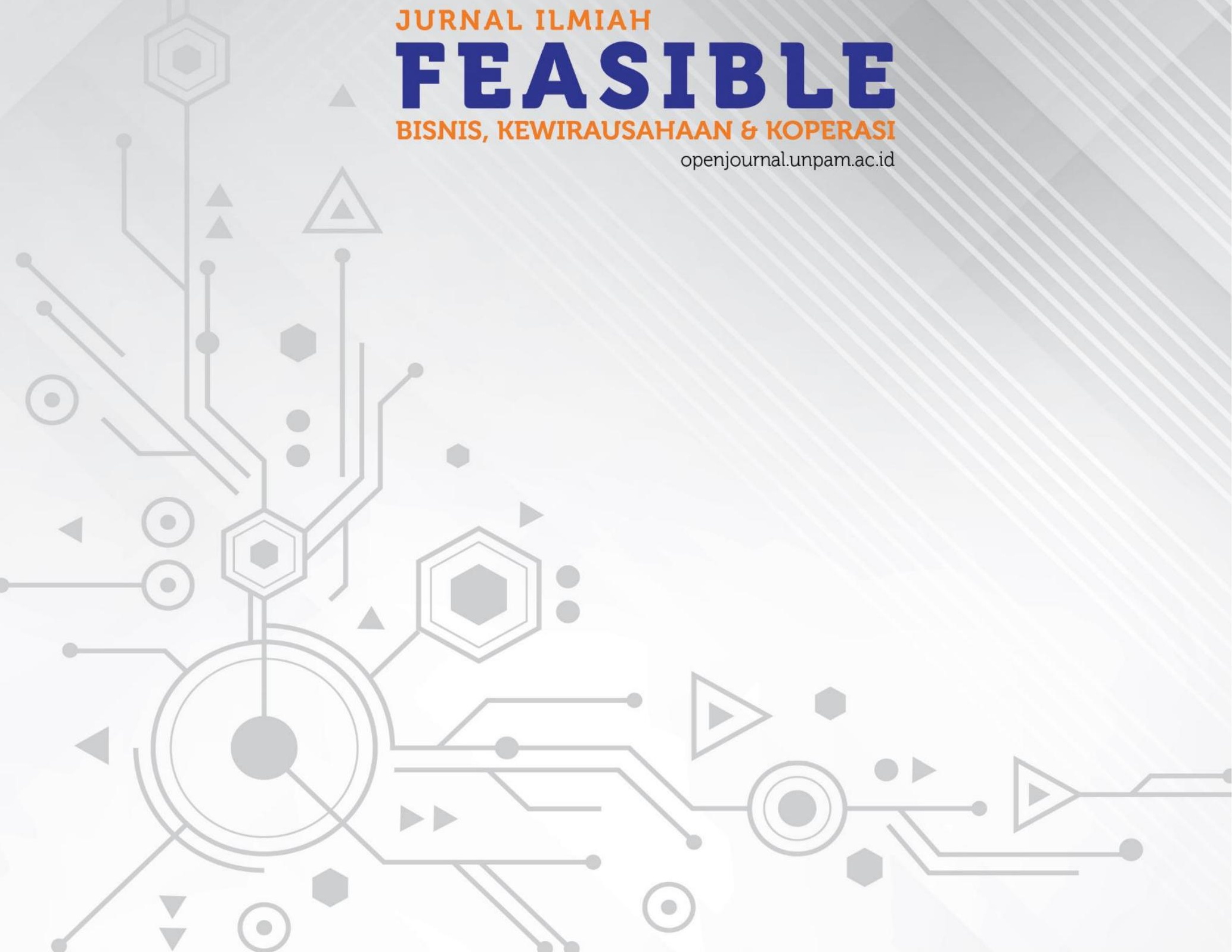




\title{
ANALISIS RASIO SOLVABILITAS DAN PROFITABILITAS UNTUK MENILAI KINERJA KEUANGAN PT SRI REJEKI ISMAN Tbk
}

\author{
Sunanto'); Putri, S.W.I.2) \\ Prodi Manajemen Universitas Pamulang \\ sunantoapt@gmail.com
}

\begin{abstract}
Abstrak
Tujuan penelitian ini adalah untuk mengetahui kinerja keuangan PT. Sri Rejeki Isman Tbk periode tahun 2013-2017 dengan parameter rasio solvabilitas dan profitabilitas. Metode penelitian yang digunakan adalah deskriptif dengan pendekatan kuantitatif dengan populasi laporan keuangan periode tahun 2013 - 2017. Rasio solvabilitas diukur dengan Debt To Equity Ratio (DER) dan Debt To Asset Ratio (DAR.) Sedangkan Rasio Profitabilitas dengan rumus Nett Profit Margin (NPM) dan Gross Profit Margin (GPM). Hasil penelitian bila dibandingkan dengan rata-rata standar industri menunjukan rasio solvabilitas DER rata-rata selama tahun 2013-2017 dalam kondisi sehat sebesar 176,6\% (sehat: DER >150\%200\%), sementara DAR dalam kondisi tidak sehat yaitu sebesar 63,6\% (tidak sehat: $D A R \leq 100 \%)$. Untuk rasio profitabilitas dibandingkan rata-rata standar industri menunjukkan kinerja yang baik dengan Nett Profit Margin (NPM)) sebesar 8,1\% (sehat: $N P M>8 \%-12 \%$ ), Gross Profit Margin (GPM) sebesar 20,7\% (sangat sehat: GPM>12\%).
\end{abstract}

Kata Kunci : Debt To Asset Ratio (DAR); Debt To Equity Ratio (DER); Nett Profit Margin (NPM); Gross Profit Margin (GPM; Kinerja.

\begin{abstract}
The purpose of this study is to determine the financial performance of PT Sri Rejeki Isman Tbk for the period of 2013 - 2017 with the parameters of solvency and profitability ratios. The research method used is descriptive quantitative approach to the population of financial statements for the period of 2013-2017. Solvency ratios are measured by Debt to Equity Ratio (DER) and Debt to Asset Ratio (DAR.) While the Profitability Ratio with the formula Nett Profit Margin (NPM) and Gross Profit Margin (GPM). The results of the study when compared with the average industry standard showed an average DER solvency ratio during 2013-2017 in a healthy condition of 176.6\% (healthy: DER $>150 \%-200 \%$ ), while DAR in unhealthy conditions that is equal to $63.6 \%$ (unhealthy: DAR $\leq 100 \%$ ). For profitability ratios compared to the average industry standard showed good performance with Nett Profit Margin (NPM) of 8.1\% (healthy: NPM> 8\% -12\%), Gross Profit Margin (GPM) of $20.7 \%$ (very healthy: GPM>12\%)
\end{abstract}

Key Words: Debt To Asset Ratio (DAR); Debt To Equity Ratio (DER); Nett Profit Margin (NPM); Gross Profit Margin (GPM, Kinerja. 


\section{PENDAHULUAN}

\section{Latar Belakang}

Setiap perusahaan mempunyai tujuan yang sama yaitu profit (laba), growth (pertumbuhan), survive (kelangsungan hidup perusahaan) dan tujuan perusahaan tersebut harus dicapai oleh semua pihak yang ada dalam perusahaan. Tujuan tersebut membutuhkan pengelolaan serta laporan keuangan yang baik. Menurut Kasmir (2016), laporan keuangan merupakan laporan yang menunjukkan suatu kondisi keuangan perusahaan baik pada saat ini atau dalam suatu periode tertentu. Setiap perusahaan harus mengetahui laporan keuangan dasar yang mengukur posisi keuangan perusahaan, meliputi: neraca, laporan laba-rugi, dan laporan arus kas. Laporan keuangan memberikan berbagai informasi yang dapat digunakan oleh pemimpin perusahaan atau investor untuk menilai kondisi suatu perusahaan.

Untuk menilai kondisi keuangan, pihak manajemen perusahaan memerlukan tolak ukur yang umumnya digunakan dalam perusahaan yaitu rasio analis rasio (analysis ratio). Kasmir (2016) menjelaskan bahwa rasio keuangan merupakan kegiatan membandingkan angka-angka yang ada dalam laporan keuangan dengan cara membagi satu angka dengan angka yang lainnya. Analisis rasio berorientasi pada masa depan yaitu memprediksi keadaan yang akan dialami oleh perusahaan. Hampir semua perusahaan menggunakan rasio untuk mengevaluasi sebaik apa kinerja perusahaan terkait dengan operasionalnya, pengaruh ekonomi secara keseluruhan dan pesaing yang ada. Dengan demikian kegunaan atau manfaat suatu angka rasio tergantung pada kemampuan dan kecerdasaan manajemen atau analis dalam menginterprestasikan data yang ada untuk menilai dan mengukur kinerja keuangan perusahaan, karena data yang tercatum dalam laporan keuangan mencerminkan kinerja keuangan dan merupakan jendela untuk melihat aktifitas perubahan.

PT Sri Rejeki Isman Tbk atau disebut Sritex merupakan perusahaan yang bergerak dalam bidang teksti-garmen. Perusahaan memulai kegiatan komersial pada tahun 1978. Kantor pusat Sritex berkedudukan di Jalan K.H. Samanhudi No. 88, Jetis, Sukoharjo 57511, Solo, Jawa Tengah - Indonesia. Induk usaha Sritex adalah PT Huddleston Indonesia (dahulu bernama PT Busana Indah Makmur), sedangkan pemegang saham terakhir Sritex adalah Huddleston Enterprises Pte. Ltd (59\%), Keluarga Lukminto dan masyarakat (40\%). Perusahaan Sritex merupakan salah satu contoh perusahaan tekstil di Indonesia yang merupakan perusahaan padat karya yang sangat rentan terhadap volatilitas tenaga kerja dan kondisi ekonomi nasional dan maupun global. Perusahaan yang mampu bertahan dalam jangka waktu lama dapat diduga terkait kinerja perusahaan terutama kinerja keuangnnya. 


\begin{tabular}{|c|c|c|c|c|}
\hline \multicolumn{5}{|c|}{$\begin{array}{l}\text { Tabel 1. Data Keuangan } \\
\text { PT. Sri Rejeki Isman, Tbk } \\
\text { Tahun } 2013-2017\end{array}$} \\
\hline Deskripsi & $\begin{array}{c}\text { Tahun } \\
2013\end{array}$ & $\begin{array}{c}\text { Tahun } \\
2017\end{array}$ & $\begin{array}{c}\text { \%Growt } \\
\mathrm{h}\end{array}$ & $\begin{array}{c}\% \text { Av. } \\
\text { Growt } \\
\text { h }\end{array}$ \\
\hline $\begin{array}{l}\text { Total } \\
\text { Aset }\end{array}$ & 458.662 .028 & 1.192 .901 .083 & $160,08 \%$ & $40,02 \%$ \\
\hline $\begin{array}{l}\text { Total } \\
\text { Ekuitas }\end{array}$ & 269.084 .595 & 750.742 .209 & $179,00 \%$ & $44,75 \%$ \\
\hline $\begin{array}{l}\text { Total } \\
\text { Hutang }\end{array}$ & 189.577 .424 & 442.158 .829 & $133,23 \%$ & $33,31 \%$ \\
\hline $\begin{array}{l}\text { Penjuala } \\
n\end{array}$ & 546.960 .954 & 759.349 .865 & $38,83 \%$ & $9,71 \%$ \\
\hline $\begin{array}{l}\text { Laba } \\
\text { Bersih }\end{array}$ & 29.677 .022 & 68.035 .320 & $129,25 \%$ & $32,31 \%$ \\
\hline
\end{tabular}

Berdasarkan paparan data diatas, terlihat masing-masing indikator mempunyai pertumbuhannya berbeda baik secara kumulatif maupun rata-rata selama empat tahun. Kondisi ini merupakan gambaran umum perusahaan yang perlu diperdalam dengan variabel variabel keuangan yang lebih spesifik untuk mengetahui kinerja perusahaan apakah dalam kondisi sehat atau tidak sehat. Mengingat luasnya ruang lingkup yang dapat di evaluasi, maka penulis membatasi pembahasan kinerja keuangan ini terkait variabel rasio solvabilitas dan rasio profitabilitas berdasarkan data laporan keuangan perusahaan periode tahun 2013 sampai dengan tahun 2017.

\section{Rumusan Masalah}

Berdasarkan latar belakang tersebut di atas maka masalah-masalah penelitian ini dapat di rumuskan sebagai berikut :

1. Bagaimana Debt to Total Asset Ratio PT Sri Rejeki Isman Tbk Periode 20132017?

2. Bagaimana Debt to Equity Ratio PT Sri Rejeki Isman Tbk Periode 2013 - 2017?
3. Bagaimana Gross Profit Margin PT Sri Rejeki Isman Tbk Periode 2013 - 2017?

4. Bagaimana Net Profit Margin PT Sri Rejeki Isman Tbk Periode 2013 - 2017?

5. Bagaimana kinerja keuangan PT Sri Rejeki Isman Tbk Periode 2013 - 2017?

\section{Tujuan Penelitian}

1. Untuk mengetahui Debt to Total Asset Ratio PT Sri Rejeki Isman Tbk.Periode 2013- 2017

2. Untuk mengetahui Debt to Equity Ratio PT. Sri Rejeki Isman Tbk. Periode 20132017

3. Untuk mengetahui Gross Profit Margin PT Sri Rejeki Isman Tbk Periode 20132017

4. Untuk mengetahui Net Profit Margin PT Sri Rejeki Isman Tbk. Periode 2013 2017

5. Untuk mengetahui kinerja keuangan PT. Sri Rejeki Isman Tbk. Periode tahun 2013- 2017

\section{Kajian Literatur \\ Kinerja Keuangan}

Menurut Hanafi (2007:69) Pengukuran kinerja keuangan didefinisikan sebagai "performing measurement" yaitu kualifikasi dan efisiensi serta efektivitas perusahaan dalam pengoperasian bisnis selama periode akuntansi. Dengan demikian kinerja adalah suatu usaha formal yang dilaksanakan perusahaan untuk mengevaluasi efisien dan efektivitas dari aktivitas perusahaan yang telah dilaksanakan pada periode waktu tertentu. Menurut Munawir (2012:31) menyatakan 
bahwa tujuan dari pengukuran kinerja keuangan perusahaan adalah:

1. Mengetahui tingkat likuiditas

Likuiditas menunjukan kemampuan suatu perusahaan untuk memenuhi kewajiban keuangan yang harus segera diselesaikan pada saat ditagih.

2. Mengetahui tingkat solvabilitas

Solvabilitas menunjukan kemampuan perusahaan untuk memenuhi kewajiban keuangannya apabila perusahaan tersebut dilikuidasi baik keuangan jangka pendek maupun jangka panjang.

3. Mengetahui tingkat profitabilitas

Profitabilitas menunjukan kemampuan perusahaan untuk menghasilkan laba selama periode tertentu.

4. Mengetahui tingkat stabilitas

Stabilitas menunjukan kemampuan perusahaan untuk melakukan usahanya dengan stabil, yang diukur dengan mempertimbangkan kemampuan perusahaan untuk membayar hutang - hutangnya serta membayar beban bunga tepat pada waktunya.

\section{Rasio Solvabilitas}

Rasio Solvabilitas adalah rasio untuk mengukur seberapa besar perusahaan dibiayai dengan hutang (Irham Fahmi, 2014:62). Rasio ini digunakan untuk mengukur sejauh mana aset perusahaan dibiayai oleh hutang atau dengan kata lain rasio yang digunakan untuk mengukur seberapa besar beban hutang yang harus ditanggung perusahaan dalam rangka pemenuhan aset. Semakin rendah tingkat rasio solvabilitas dari standar industri perusahaan maka semakin besar hutang yang dibiayai oleh aset perusahaan atau perusahaan tersebut dalam keadaan tidak sehat. Adapun pengukuran rasio solvabilitas yang digunakan dalam penelitian ini, yaitu:

\section{Debt to Total Assets Ratio}

Rasio yang biasa disebut rasio hutang (debt ratio) ini mengukur prosentase besarnya dana yang berasal dari hutang. Hutang yang dimaksud adalah semua hutang yang dimiliki oleh perusahaan baik berjangka pendek maupun yang berjangka panjang. Kredior lebih menyukai debt ratio yang rendah sebab tingkat keamanan dananya mejadi semakin baik (Sutrisno, 2001:249). Rasio ini menunjukan sejauh mana hutang dapat ditutupi oleh aktiva. Semakin kecil rasionya semakin aman (solvable). Porsi hutang terhadap aktiva harus lebih kecil (harahap, 2002:304). Untuk mengukur besarnya rasio hutang ini digunakan rumus:

Debt to Asset Ratio $=\frac{\text { Total } \text { Hutang }}{\text { Total Aktiva }} \times 100 \%$

\section{Debt to Equity Ratio}

Rasio hutang dengan modal sendiri (Debt To Equity Ratio) atau DER adalah imbangan antara hutang yang dimiliki perusahaan dengan modal sendiri. Semakin tinggi rasio ini berarti modal sendiri semakin sedikit dibanding dengan hutangnya. Bagi perusahaan sebaiknya, besarnya hutang tidak boleh melebihi 
modal itu sendiri agar beban tetapnya tidak terlalu tinggi. Semakin kecil rasio ini semakin baik. Maksudnya, semakin kecil porsi hutang tergadap modal, semakin aman. Rasio ini dirumuskan :

Debt to Equity Ratio $=\frac{\text { Total } \mathrm{Hutang}}{\text { Modal }} \times 100 \%$

\section{Rasio Profitabilitas}

Rasio profitabilitas merupakan rasio yang digunakan untuk mengukur kemampuan suatu perusahaan dalam mendapatkan laba. Perhatian ditekankan pada rasio ini karena hal ini berkaitan erat dengan kelangsungan hidup perusahaan. Ada beberapa ukuran rasio profitabilitas yang dipakai antara lain:

\section{Gross Profit Margin}

Gross Profit Margin (GPM) merupakan perbandingan antara laba kotor yang diperoleh perusahaan dengan tingkat penjualan yang dicapai pada periode yang sama. Rasio ini mencerminkan atau menggambarkan laba kotor yang pada dicapai setiap rupiah penjualan. Semakin besar rasionya berarti semakin baik kondisi keuangan perusahaan. Rasio ini di rumuskan dengan :

Gross Profit Margin $=\frac{\text { Laba Kotor }}{\text { Penjualan bersih }} \mathrm{x}$ $100 \%$

\section{Net Profit Margin}

Net Profit Margin (NPM) atau margin laba bersih digunakan untuk mengukur rupiah laba bersih yang dihasilkan oleh setiap satu rupiah penjualan dan mengukur seluruh efisien, baik produksi, administrasi, pemasaran, pendanaan penentuan harga maupun manajemen pajak. Semakin tinggi rasionya menunjukan kemampuan perusahaan menghasilkan laba yang tinggi pada tingkat penjualan tertentu, akan tetapi jika rasionya rendah menunjukan penjualan terlalu rendah untuk tingkat biaya tertentu atau biaya yang terlalu tingi untuk tingkat penjualan tertentu, bisa juga kombinasi dari kedua hal tersebut. Rasio ini dapat dihitung dengan rumus :

$\mathrm{NPM}=\frac{\text { Laba Bersih Setelah Pajak }}{\text { Penjualan Bersih }} \times 100 \%$

\section{METODE}

\section{Jenis Penelitian}

Jenis penelitian ini adalah deskriptif dengan pendekatan kuantitatif. dimana hal yang di deskripsikan di catat, di analisis dan di interprestasikan. Data-data analisis adalah data yang bersifat kuantitatif yaitu data-data yang bersifat angka (Sugiyono,2016:23). Dalam penelitian digunakan data sekunder yang yang bersumber dari laporan keuangan PT Sri Rejeki Isman Tbk periode 2013-2017.

\section{Operasional Variabel Penelitian}

Menurut Sugiyono (2016:38) variabel penelitian pada dasarnya adalah segala sesuatu yang berbentuk apa saja yang ditetapkan oleh peneliti untuk dipelajari sehingga diperoleh informasi tentang hal tersebut, kemudian ditarik kesimpulannya. Dharma dalam Martias (2017:2) menyatakan bahwa definisi operasional merupakan penjelasan semua variabel dan istilah yang akan digunakan dalam 
penelitian. Adapun definisi operasional variabel dalam penelitian ini dapat diuraikan sebagai berikut:

\section{Populasi dan Sampel}

Menurut (Sugiyono 2016:119) populasi adalah wilayah generalisasi yang terdiri dari objek atau subjek yang mempunyai kualitas dan karakteristik tertentu yang di tetapkan oleh peneliti untuk di pelajari dan kemudian di tarik kesimpulannya. Jadi, populasi tidak hanya berupa orang tetapi juga objek dan benda alam lainnya. Populasi dalam penelitian ini adalah laporan keuangan PT Sri Rejeki Isman Tbk dengan sampel berupa laporan neraca dan laporan laba/rugi periode 2013-2017.

\section{Teknik Pengumpulan Data}

Peneliti menggunakan data sekunder dengan metode pengumpulan data berupa library research dan documentation research. Peneliti mendapatkan data yang dapat dipergunakan dalam penelitian ini dengan membaca literature seperti bukubuku, jurnal, artikel, majalah, dan hal lain yang berhubungan dengan hal-hal yang diteliti sebagai upaya dalam memperoleh data-data yang valid. Pengumpulan data dari data dokumen berupa laporan keuangan tahun 2010 sampai dengan tahun 2017 yang digunakan untuk mengungkapkan hal-hal yang berhubungan dengan neraca dan laporan laba rugi PT Sri Rejeki Isman Tbk.

\section{Teknik Analisis Data}

Adapun metode analisis data dalam penelitian ini menggunakan metode analisis rasio keuangan yaitu rasio solvabilitas, dan rasio profitabilitas. Dengan analisis rasio ini penulis dapat membandingkan keadaan perusahaan dari satu periode ke periode lainnya sehingga dapat diketahui peningkatan atau penurunan kinerja keuangan perusahaan. Adapun tolak ukur yang digunakan dalam melakukan penelitian kinerja keuangan perusahaan dengan menggunakan standar industri dari Keputusan Menteri Keuangan Republik Indonesia Nomor: 740/KMK.oo/ 1989 sebagai berikut :

\begin{tabular}{|c|c|c|c|c|}
\hline \multicolumn{5}{|c|}{ Tabel 1.2. Rasio Standar Industri } \\
\hline $\begin{array}{c}\text { Rasio } \\
\text { Keuangan }\end{array}$ & $\begin{array}{l}\text { Sehat } \\
\text { Sekali }\end{array}$ & Sehat & $\begin{array}{l}\text { Kurang } \\
\text { Sehat }\end{array}$ & $\begin{array}{l}\text { Tidak } \\
\text { Sehat }\end{array}$ \\
\hline $\begin{array}{l}\text { Rasio } \\
\text { Solvabilitas }\end{array}$ & $\begin{array}{c}>200 \\
\%\end{array}$ & $\begin{array}{c}>150 \\
\%- \\
200 \%\end{array}$ & $\begin{array}{c}>100 \\
\%- \\
150 \%\end{array}$ & $\begin{array}{c}<100 \\
\%\end{array}$ \\
\hline $\begin{array}{l}\text { Rasio } \\
\text { Profitabilita } \\
\text { S }\end{array}$ & $>12 \%$ & $\begin{array}{c}>8 \%- \\
12 \%\end{array}$ & $\begin{array}{c}>5 \%- \\
8 \%\end{array}$ & $<5 \%$ \\
\hline Sumber: & Keputusan & & & Keuangan \\
\hline Vo:740/KMK. & 989. & & & \\
\hline
\end{tabular}

\section{HASIL dan PEMBAHASAN Objek Penelitian}

PT Sri Rejeki Isman Tbk merupakan perusahaan tekstil garmen terpadu dengan lebih dari 17 ribu karyawan yang mengkonsentrasikan sebagian besar operasinya di lahan seluas 70 hektar di Sukoharjo, Jawa Tengah. Pada 2015, penjualan garment di Sritex menyumbang sebesar 21,5\%. Lokasi geografis Sritex dan pasokan tenaga kerja yang terampil dan 
relatif kompetitif dibandingkan dengan wilayah lain di Indonesia telah berkontribusi langsung terhadap terpenuhinya kualitas dan kuantitas produk yang dibutuhkan pelanggan dengan mempertahankan struktur biaya rendah dan margin keuntungan yang sehat.

Tabel 1.3. Neraca PT Sri Rejeki Isman Tbk Tahun 2013 - 2017

\begin{tabular}{|c|c|c|c|c|c|c|}
\hline Balance Sheet/ Neraca & Dec-2013 & Dec-2014 & Dec-2015 & Dec-2016 & Dec-2017 & AVERACE \\
\hline Millions RP except par valus & & & & & & \\
\hline Kas dan Setara Kas & $6,107,134$ & $81,604,263$ & $77,136,595$ & $60,487,294$ & $127,323,030$ & $70,531,663$ \\
\hline Piutang Usaha & $60,802,823$ & $129,239,679$ & $102,181,939$ & $149,560,622$ & $188,659,054$ & $126,088,823$ \\
\hline Persediaan & $119,668,358$ & $109,569,858$ & $135,788,325$ & $147,615,967$ & $266,238,820$ & $155,776,266$ \\
\hline Total Current Assets/Aset Lancar & $129,152,619$ & $326,243,695$ & $323,137,765$ & $378,025,198$ & $645,050,740$ & $360,322,003$ \\
\hline Pertumbuhan/Growth (\%) & $0 \%$ & $153 \%$ & $-1 \%$ & $17 \%$ & $71 \%$ & \\
\hline Aset Tetap & $250,034,625$ & $322,597,417$ & $440,876,907$ & $519,304,496$ & $546,707,929$ & $415,904,275$ \\
\hline $\begin{array}{l}\text { Total Fixed Asset/Aset Tidak } \\
\text { Lancar } \\
\end{array}$ & $266,509,400$ & $372,622,209$ & $460,208,965$ & $569,144,512$ & $547,850,298$ & $443,267,077$ \\
\hline Pertumbuhan/Growth (\%) & $0 \%$ & $40 \%$ & $24 \%$ & $24 \%$ & $-4 \%$ & \\
\hline Total Assets/Total Aktiva & $458,662,019$ & $698,865,904$ & $783,346,730$ & $947,169,710$ & $1,192,901,038$ & $816,189,080$ \\
\hline Pertumbuhan/Growth (\%) & $0 \%$ & $52 \%$ & $12 \%$ & $21 \%$ & $26 \%$ & \\
\hline Hutang Jangka Pendek/CL & $183,143,613$ & $64,484,971$ & $67,155,332$ & $123,527,900$ & $175,187,960$ & $122,699,955$ \\
\hline Hutang Jangka Panjang/LTL & $85,940,982$ & $402,948,158$ & $439,450,226$ & $492,532,302$ & $575,554,249$ & $399,285,183$ \\
\hline Total Hutang & $269,084,595$ & $467,433,129$ & $506,605,558$ & $616,060,202$ & $750,742,209$ & \\
\hline
\end{tabular}

Sumber: IDX

Tabel 1.4. Data Laporan Laba/Rugi PT Sri Rejeki Isman Tbk

Tahun 2013- 2017

Kode Perusahaan : SRIL

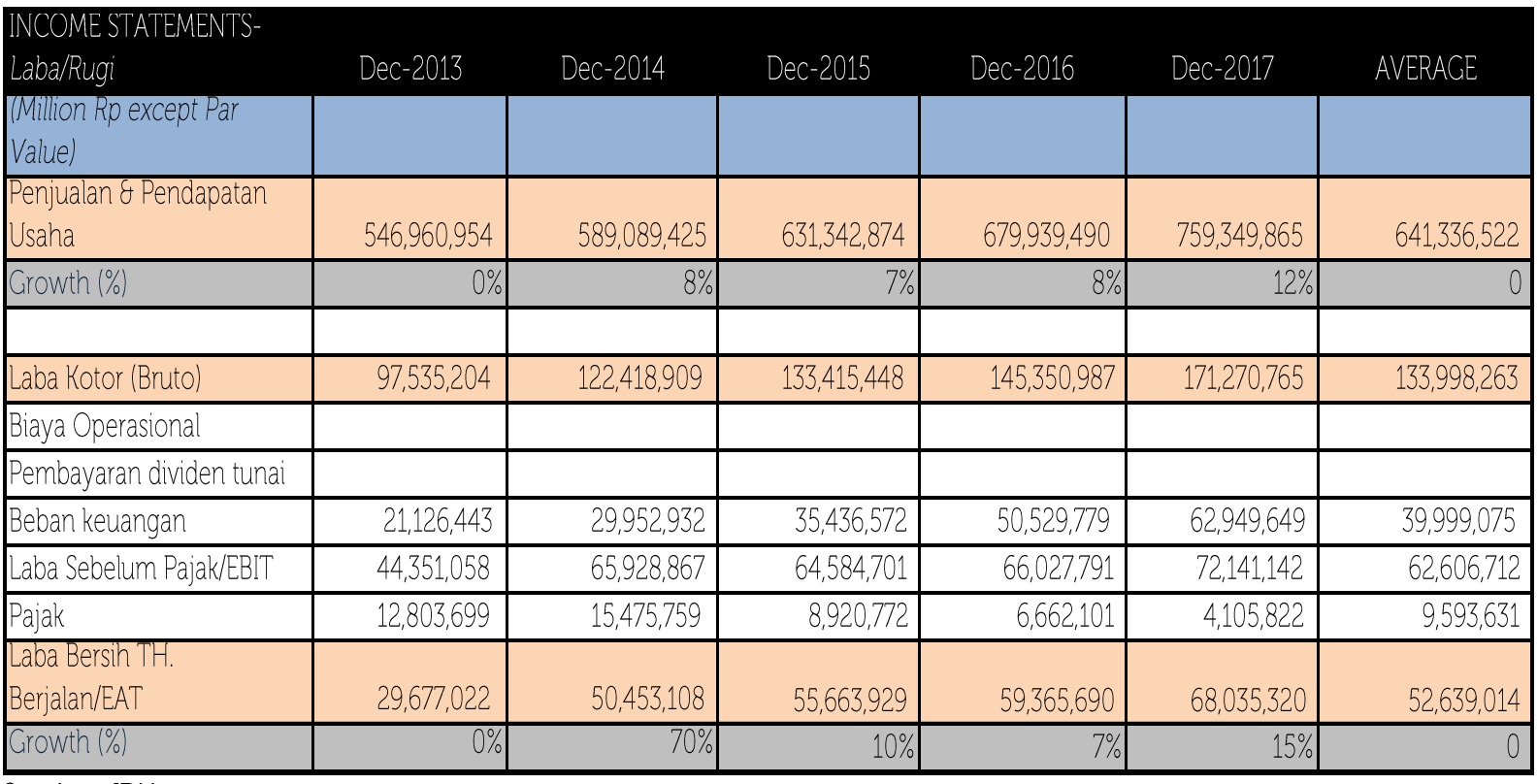

Sumber: IDX 
Adapun hasil perhitungan rasionya adalah sebagai berikut :

\section{Rasio Solvabilitas}

Tabel 1.5. Hasil Perhitungan

Debt To Equity Ratio PT Sri Rejeki Isman Tbk Tahun 2013 - 2017

\begin{tabular}{|c|c|c|c|c|c|}
\hline Tahun & $\begin{array}{l}\text { Total Hutang } \\
\text { (A) }\end{array}$ & Modal (B) & $\begin{array}{c}\text { Presen } \\
\text { tase }\end{array}$ & $\begin{array}{c}\text { DER } \\
(A / B) \times C\end{array}$ & Ket, \\
\hline 2013 & $269,084,595$ & $189,577,424$ & $100 \%$ & $141.9 \%$ & \\
\hline 2014 & $467,433,129$ & $231,432,775$ & $100 \%$ & $202.0 \%$ & Naik \\
\hline 2015 & $506,605,558$ & $276,741,172$ & $100 \%$ & $183.1 \%$ & Turun \\
\hline 2016 & $616,060,202$ & $331,109,508$ & $100 \%$ & $186.1 \%$ & Naik \\
\hline 2017 & $750,742,209$ & $442,158,829$ & $100 \%$ & $169.8 \%$ & Turun \\
\hline
\end{tabular}

Tabel 1.6. Hasil Perhitungan

Debt To Assets Ratio PT Sri Rejeki Isman Tbk

Tahun 2013 - 2017

\begin{tabular}{|c|c|c|c|c|c|}
\hline Tahun & $\begin{array}{c}\text { Totall utang } \\
\text { A) }\end{array}$ & Totali ktija (B) & $\begin{array}{c}\text { Presen } \\
\text { tase }\end{array}$ & $\begin{array}{c}D A R \\
A B \mid X C\end{array}$ & $\mathrm{Ke}$ \\
\hline & $269,084,595$ & $458,662,019$ & $100 \%$ & $58.7 \%$ & \\
\hline 2014 & $467,433,129$ & $698,865,904$ & $100 \%$ & $66.9 \%$ & Nail \\
\hline 2015 & $506,605,558$ & $783,346,730$ & $100 \%$ & $64.7 \%$ & Turur \\
\hline 2016 & $616,060,202$ & $947,169,710$ & $100 \%$ & $65.0 \%$ & \\
\hline & $750,742,209$ & $1,192,901,038$ & $100 \%$ & $62.9 \%$ & Turl \\
\hline
\end{tabular}

Sumber: IDX (data diolah)

Tabel 1.7. Hasil Perhitungan Solvabilitas PT. Sri Rejeki Isman, Tbk Tahun 2013 - 2017

\begin{tabular}{|l|c|c|c|c|c|c|c|}
\hline Jenis & \multicolumn{3}{c|}{ Tahun } \\
Rasio & 2013 & 2014 & 2015 & 2016 & 2017 & Average & Kreteria \\
\hline DER & $141.9 \%$ & $202.0 \%$ & $183.1 \%$ & $186.1 \%$ & $169.8 \%$ & $176.0 \%$ & Sehat \\
\hline DAR & $58.7 \%$ & $66.9 \%$ & $64.7 \%$ & $65.0 \%$ & $62.9 \%$ & $63 . \% \%$ & $\begin{array}{l}\text { Tidak } \\
\text { Sehat }\end{array}$ \\
\hline
\end{tabular}

Sumber : IDX (data diolah)

\section{Rasio Profitabilitas}

Tabel 1.8. Hasil Perhitungan Gross Profit Margin PT. Sri Rejeki Isman,Tbk. Tahun 2013 - 2017

\begin{tabular}{|c|c|c|c|c|c|}
\hline Tahun & $\begin{array}{c}\text { Laba Kotor } \\
\text { (A) }\end{array}$ & $\begin{array}{l}\text { Penjualan } \\
\text { Bersih (B) }\end{array}$ & $\begin{array}{c}\text { Presen } \\
\text { tase }\end{array}$ & $\begin{array}{l}\text { CPM } \\
(A / B) \times C\end{array}$ & \\
\hline 2013 & $97,535,204$ & $546,960,954$ & $100 \%$ & $17.8 \%$ & \\
\hline 2014 & $122,418,909$ & $589,089,425$ & $100 \%$ & $20.8 \%$ & Naik \\
\hline 2015 & $133,415,448$ & $631,342,874$ & $100 \%$ & $21.1 \%$ & Naik \\
\hline 2016 & $145,350,987$ & $679,939,490$ & $100 \%$ & $21.4 \%$ & Naik \\
\hline 2017 & $171,270,765$ & $759,349,865$ & $100 \%$ & $22.6 \%$ & Naik \\
\hline
\end{tabular}

Sumber : IDX (data diolah)

\section{Tabel 1.9. Hasil Perhitungan Net Profit Margin PT. Sri Rejeki Isman,Tbk.} Tahun 2013 - 2017

\begin{tabular}{|c|c|c|c|c|c|}
\hline Tahun & $\begin{array}{c}\text { Laba B ersh } \\
\text { Setelah } \\
\text { Pajak (A) }\end{array}$ & $\begin{array}{l}\text { Penjialan } \\
\text { B ersh (B) }\end{array}$ & P resentase & $\begin{array}{c}\text { NPM } \\
(A / B \mid X C\end{array}$ & Ket. \\
\hline 2013 & $29,677,022$ & $546,960,954$ & $100 \%$ & $5.4 \%$ & \\
\hline 2014 & $50,453,108$ & $589,089,425$ & $100 \%$ & $8.6 \%$ & Naik \\
\hline 2015 & $55,663,929$ & $631,342,874$ & $100 \%$ & $88 \%$ & Nak \\
\hline 2016 & $59,365,690$ & $679,939,490$ & $100 \%$ & $8.7 \%$ & Tumn \\
\hline 2017 & $68,035,320$ & $759,349,865$ & $100 \%$ & $9.8 \%$ & Nak \\
\hline
\end{tabular}

Sumber : IDX (data diolah)

\section{Tabel 10. Hasil Perhitungan Rasio Profitabilitas PT Sri Rejeki Isman Tbk Tahun 2013 - 2017}

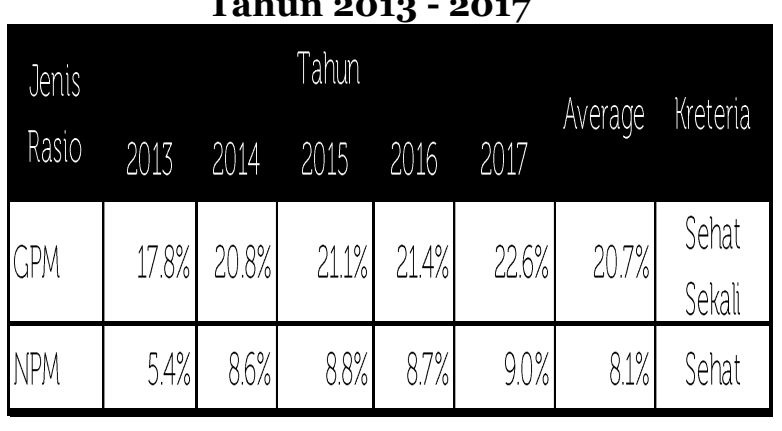

Sumber : IDX (data diolah) 


\section{Pembahasan}

1. Debt to Equity Ratio PT Sri Rejeki Isman Tbk Periode 2013- 2017

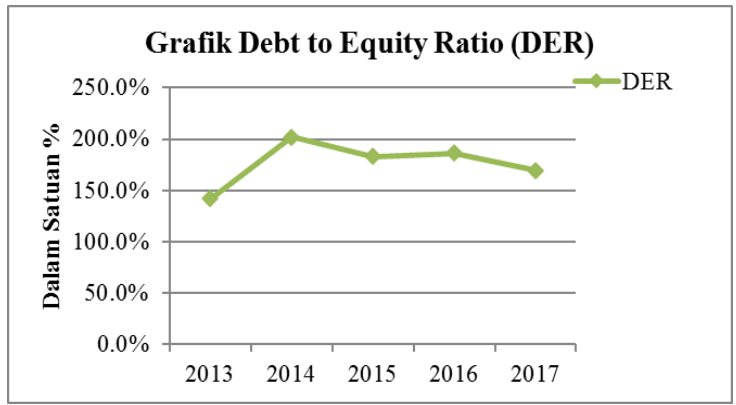

Gambar 1. 1. Debt to Equity Ratio PT Sri Rejeki Isman Tbk 2013-2017

Dari data di atas dapat di simpulkan bahwa debt to equity ratio mengalami keadaan fluktuatif dari tahun ke tahun yaitu adanya kenaikan dan penurunan pada setiap tahunnya. Hal ini karena adanya total hutang yang meningkat setiap tahunnya dengan rata-rata $1,204 \%$ dan rata-rata kenaikan total modal sebesar $631 \%$.

\section{Debt to Total Asset Ratio PT Sri Rejeki} Isman Tbk Periode 2013 - 2017

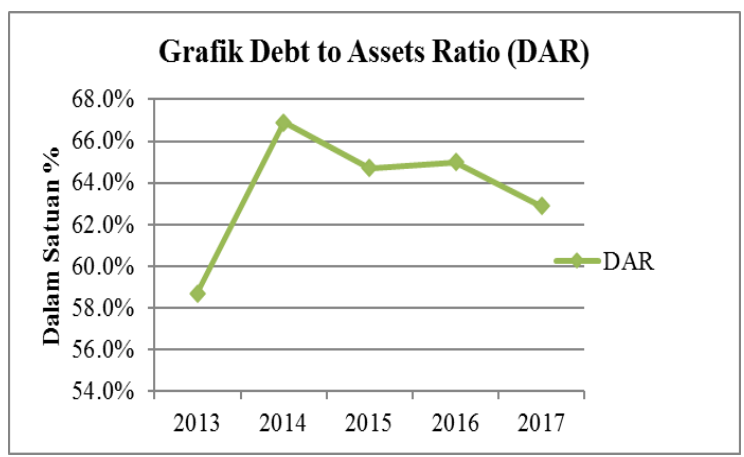

Gambar 1.2. Debt to Assets Ratio PT Sri Rejeki Isman Tbk 2013 - 2017

Dari data diatas dapat di simpulkan bahwa debt to assets ratio mengalami keadaan fluktuatif dari tahun ke tahun yaitu adanya penurunan pada tahun 2015 dan 2017, sementara mengalami kenaikan pada tahun 2014 dan 2016. Hal ini karena adanya total hutang yang mengalam peningkatan dan penurunan dengan rata rata sebesar 1,204\% dan total aktiva yang mengalami kenaikan atau penurunan dengan rata - rata sebesar 1,835\% dari tahun sebelumnya.

3. Gross Profit Margin PT Sri Rejeki Isman Tbk Periode 2013 - 2017

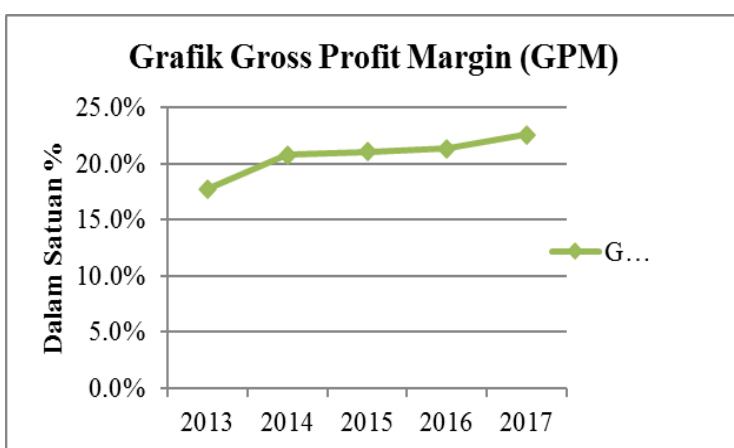

Gambar 1.3. Grafik Gross Profit Margin PT Sri Rejeki Isman Tbk

Tahun 2013 - 2017

Dari data diatas dapat digambarkan bahwa gross profit margin PT Sri Rejeki Isman Tbk mengalami kenaikan dari setiap tahunnya. Hal ini di karenakan jumlah laba bersih dengan rata-rata $21 \%$ mengalami kenaikan dari tahun ke tahun.

4. Gross Profit Margin PT Sri Rejeki Isman Tbk Periode 2013 - 2017

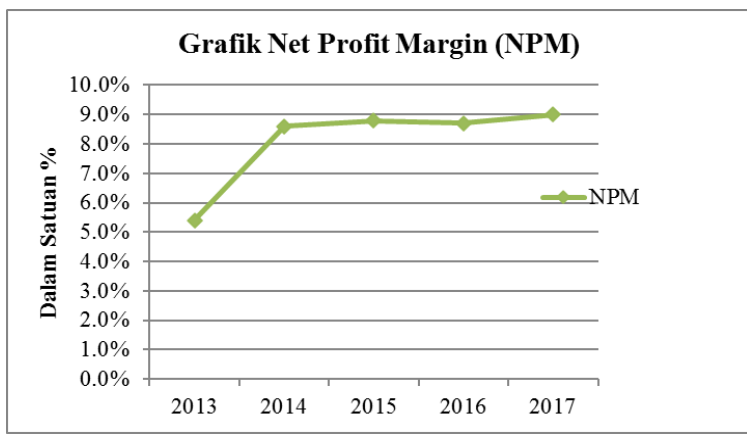

Gambar 1.4. Grafik Net Profit Margin PT Sri Rejeki Isman Tbk Tahun 2013 - 2017 
Dari data diatas dapat disimpulkan bahwa nett profit margin PT. Sri Rejeki Isman, Tbk mengalami keadaaan fluktuatif atau kenaikan dan penurunan dari setiap tahunnya. Hal ini di karenakan jumlah laba bersih dengan rata -rata 8,1\% mengalami kenaikan dan penurunan dari tahun ke tahun

\section{Kinerja Keuangan PT Sri Rejeki Isman Tbk Periode Tahun 2013 - 2017}

Untuk mengukur kinerja keuangan PT. Sri Rejeki Isman,Tbk. Penulis melakukan perhitungan rata- rata terlebih dahulu untuk rasio keuangan yang di teliti. Kemudian hasilnya di bandingkan dengan standar industri rasio keuangan yang sudah di tetapkan, dan dalam penelitian ini mengacu pada standar berdasarkan Keputusan Menteri Keuangan Republik Indonesia Nomor: 740/KMK.0o/1989.

a. Kinerja Rasio Solvabilitas PT. Sri Rejeki Isman, Tbk

Rasio solvabilitas PT. Sri Rejeki Isman, Tbk yang terdiri dari Debt to Equity ratio dan Debt to Asset ratio. Standar rasio industri yaitu sebesar 200\%. Debt to equity ratio PT. Sri Rejeki Isman, Tbk selama lima tahun tersebut hampir mendekati dari angka rata - rata standar industri. Dimana debt to equty ratio mendapatkan rata - rata sebesar $176,6 \%$ dari rata-rata $150 \%$ 200\% yang menunjukan keadaan sehat. Hal ini karena adanya total hutang yang meningkat setiap tahunnya di iringi dengan total equity yang terus meningkat tiap tahunnya. Sedangkan debt to asset ratio PT. Sri Rejeki Isman, Tbk selama lima tahun menunjukan rata-rata sebesar $63,6 \%$ mengalami kondisi tidak sehat karena kurang dari 100\%. hal ini di karenakan pertumbuhan hutang yang meningkat setiap tahunnya, meskipun total aktiva perusahaan mengalami kenaikan namun tidak sebanding dengan pertumbuhan total hutangnya. Dari kedua rasio tersebut, Debt to equity ratio dan Debt to Assets Ratio artinya pendanaan perusahaan dengan menggunakan hutang lebih dominan dan semakin banyak. Maka semakin sulit bagi perusahaan memperoleh tambahan dana dari pinjaman karena di khawatirkan perusahaan tidak mampu menutupi hutang - hutangnya tersebut.

b. Kinerja Rasio Profitabilitas PT. Sri Rejeki Isman, Tbk

Rasio profitabilitas PT. Sri Rejeki Isman, Tbk yang terdiri dari gross profit margin dan net profit margin, dari kedua rasio tersebut juga memperlihatkan keadaan perusahaan yang baik. Dari rata-rata industri adalah sebesar 12\%. Rata-rata gross profit margin perusahaan di atas $12 \%$ yaitu sebesar 20,7\% menunjukan kondisi perusahaan sangat baik atau sehat sekali. Hal ini di sebabkan penjualan bersih yang di hasilkan setiap tahun bisa di manfaatkan secara maksimal, sehingga 
perusahaan dapat menghasilkan laba yang optimal atau dengan kata lain perusahaan dalam menghasilkan profit pada tahun 2013 sampai 2017. Sedangkan pada rata-rata net profit margin perusahaan adalah sebesar 8,1\%. Hal ini menunjukan kondisi perusahaan sehat dari rata-rata industri di atas 8\%-2\%. Hal ini di sebabkan net profit margin mengalami kenaikan dan penurunan setiap tahunnya.

Hasil penelitian ini sesuai dengan teori analisis rasio khususnya rasio solvabilitas dan profitabilitas dari Kasmir (2016) untuk pengukuran kinerja perusahaan dan sejalan dengan penelitian sebelumnya dari Rakhmawati dan kawan-kawan (2017) yang membuktikan bahwa rasio-rasio solvabilitas dan profitabilitas digunakan dalam pengukuran kinerja keuangan suatu perusahaan.

\section{SIMPULAN}

\section{Kesimpulan}

1. Debt to Asset Ratio PT. Sri Rejeki Isman, Tbk dari tahun 2013 sampai dengan tahun 2017 dengan rata - rata rasio sebesar 63,6 \% menunjukan kondisi tidak sehat, yaitu $<100 \%$. Hal ini dikarenakan per-tumbuhan hutang dan total aktiva yang mengalami peningkatan dan penurunan setiap tahunnya.

2. Debt to Equity Ratio PT. Sri Rejeki Isman, Tbk dari tahun 2013 sampai dengan tahun 2017 dengan rata-rata rasio sebesar 176,6 \% menunjukan kondisi sehat, yaitu > 150\%-200 \%. Hal ini dikarenakan pertumbuhan total hutang dan ekuitas perusahaan mengalami kenaikan dan penurunan yang seimbang setiap tahunnya.

3. Gross Profit Margin PT. Sri Rejeki Isman, Tbk dari tahun 2013 sampai dengan tahun 2017 dengan rata - rata rasio sebesar 20,8 \% menunjukan kondisi sehat sekali sehat, yaitu $>12 \%$. Hal ini disebabkan total aktiva yang dimiliki mengalami peningkatan dan penurunan yang sebanding dengan laba bersih yang diterima.

4. Nett Profit Margin PT. Sri Rejeki Isman, Tbk dari tahun 2013 sampai dengan tahun 2017 dengan rata-rata sebesar 8,1 \% menunjukkan bahwa kondisi sehat,yaitu > 8\% - 12\%. Hal ini terjadi karena laba bersih dan penjualan bersih perusahaan mengalami peningkatan dan penurunan setiap tahunnya.

5. Kinerja PT. Sri Rejeki Isman, Tbk dari tahun 2013 sampai dengan tahun 2017 sudah cukup baik di tinjau dengan analisis rasio solvabilitas dan rasio profitabilitas menggunakan analisis Debt to Equity Ratio, Debt to Assets Ratio, Gross Profit Margi Dan Nett Profit Margin.

\section{DAFTAR PUSTAKA}

Brigham, Eugene F. dan Joel F. Houston. 2010. Dasar-dasar Manajemen 
Keuangan. Edisi 11. Penerjemah Ali

Akbar Yulianto. Jakarta: Salemba

Empat.

Fahmi, Irham, 2014. Pengantar

Manajemen Keuangan (Teori Soal dan Jawab). Bandung: Penerbit Alfabeta

Hanafi, Mamduh M. 2007. Analisis Laporan Keuangan. Edisi ketiga. Yogyakarta: STIE YKPN

Kasmir, 2016. Analisis Laporan Keuangan. Jakarta: PT. Raja Grafindo Persada Munawir, S, 2016. Analisa Laporan Keuangan. Yogyakarta: Liberty Yogyakarta

Rakhmawati, A.N dkk. 2017. Analisis Rasio Likuiditas, Solvabilitas dan Profitabilitas Guna Mengukur Kinerja keuangan PT. Vepo Indah Pratama Gresik. Jurnal Ekonomi Akuntansi Vol 3 Issue 3.

Sugiono, 2016. Metode Penelitian

Kuantitatif Kualitatif dan R\&D.

Bandung: Alfabeta.

Sunyoto, Danang, 2013. Metodologi Penelitian Akuntansi. Bandung: PT Refika

Keputusan Menteri Keuangan Republik Indonesia Nomor :740/KMK.oo/ 1989 Tentang Peningkatan

Efisiensi Dan Produktivitas Badan Usaha Milik Negara.

https://www.sritex.co.id/id/berita/ http://www.idx.co.id 